\title{
Risk of soft tissue sarcomas and residence in the neighbourhood of an incinerator of industrial wastes
}

\author{
P Comba, V Ascoli, S Belli, M Benedetti, L Gatti, P Ricci, A Tieghi
}

Occup Environ Med 2003;60:680-683

See end of article for authors' affiliations

.....................

Correspondence to: Dr P Comba, National Institute of Health (ISS), Viale Regina Elena 299, 00161 Rome, Italy:

comba@iss.it

Accepted

2 October 2002

\begin{abstract}
Aims: To investigate the association between occurrence of soft tissue sarcomas (STS) in Mantua and residence near an incinerator of industrial wastes.

Methods: Cases were subjects with histologically confirmed primary malignant STS diagnosed 1989-98 in the population resident in Mantua and in the three neighbouring municipalities. Controls were randomly extracted from population registries, matched for age and sex. Residential history was reconstructed for all study subjects since 1960. Main residence was geographically positioned according to GPS standards.

Results: The study included 37 STS cases (17 men and 20 women) and 171 controls. The incidence of STS in the area of study was estimated as 8.8 per 100000 in men and 5.6 per 100000 in women. The odds ratio associated with residence within $2 \mathrm{~km}$, standardised by age and sex, was $31.4195 \%$ $\mathrm{Cl} 5.6$ to 176.1), based on five exposed cases. At greater distances, risk rapidly decreased, showing a fluctuation around the null value of 1 .

Conclusion: The study shows a significant increase in risk of STS associated with residence within 2 $\mathrm{km}$ of an industrial waste incinerator; an aetiological role of 2,3,7,8-tetrachlorodibenzo-p-dioxin (TCDD) can be hypothesised.
\end{abstract}

$\mathrm{E}$ arly studies from Sweden suggested an association between occupational exposure to chlorophenols and phenoxyacids and occurrence of STS ${ }^{1-3}$; several authors in different countries have subsequently provided further epidemiological evidence, and 2,3,7,8-tetrachlorodibenzo- $p$-dioxin (TCDD) impurities have been identified as the underlying causal agent. ${ }^{4-7}$ Polychlorodibenzodioxins (PCDDs), including TCDD, can be released by different industrial combustion processes, including the incineration of industrial wastes; occupational exposure to PCDD industrial wastes incinerators has been shown to be increased among maintenance workers. ${ }^{8-11}$

In 1998, a family doctor reported a suspected cluster of five cases of STS among her patients living close to the industrial area of the city of Mantua, Northern Italy (fig 1). In this area a major chemical plant has been operating since the 1950s. An incinerator of industrial wastes was also present. The cases had been diagnosed between 1984 and 1991, and the corresponding expected figure based on the Lombardy Region Cancer Registry was estimated to be in the range $0.57-1.00 .^{12}$

The aim of the present case-control study was to evaluate the association between occurrence of soft tissue sarcoma (STS) in Mantua and residence near the industrial site.

\section{METHODS}

The city of Mantua and the three neighbouring municipalities of Roncoferraro, Virgilio, and San Giorgio (fig 1) constituted the study area. Mantua is a city of 51300 inhabitants. The overall population of the three neighbouring municipalities is 21800 people. The area is characterised by being flat and rich in water. Fog is quite frequent, while winds are moderate, with a prevailing east-west direction.

The industrial area of Mantua, located southeast of the town, includes a large chemical plant, an oil refinery, a paper industry, and a mechanical plant. The chemical plant has been producing styrene from benzene since 1956; dichloroethane and chlorosoda were also produced. The incinerator of industrial wastes operated between 1974 and 1991. It could process

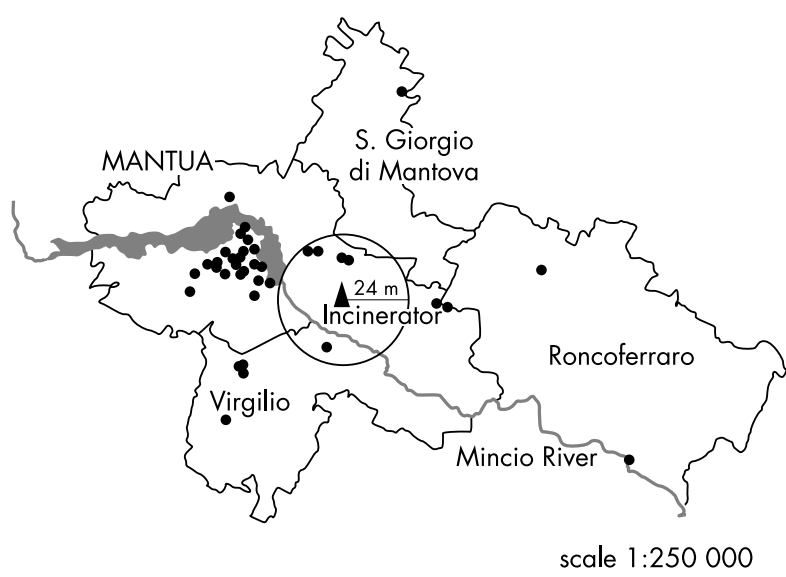

Figure 1 Case distribution in the study area. Each black dot represents one case.

$1000 \mathrm{~kg} / \mathrm{h}$ of liquid wastes and $750 \mathrm{~kg} / \mathrm{h}$ of solid wastes. Its temperature could reach $950^{\circ} \mathrm{C}$. In the years 1974-91 the incinerator treated process water, exhaust solvents, tars, pitches, exhaust resins, sludges, plastics, paper, glues, varnishes, pharmaceutical drugs, veterinary products, cosmetics, hospital wastes, and miscellaneous waste products from the farming and food industries. The majority of these wastes were classified as toxic. The chimney was $30 \mathrm{~m}$ high and had a diameter of $1.20 \mathrm{~m}$; the emission rate was about 30000 cubic metres per hour. After 1991, the activity of the incinerator underwent a major reduction.

Abbreviations: $\mathrm{Cl}$, confidence interval; GPS, global positioning system; NOS, no other specification; OR, odds ratio; PCDDs,

polychlorodibenzodioxins; PCDFs, polychlorodibenzofurans; STS, soft tissue sarcomas; TCDD, tetrachlorodibenzo-p-dioxin 
Table 1 Distribution of 37 STS cases residing in the study area according to histology, gender, and site

\begin{tabular}{|c|c|c|c|c|c|c|}
\hline \multirow[b]{2}{*}{ Morphology } & \multirow{2}{*}{$\begin{array}{l}\text { ICD-O* } \\
\text { code }\end{array}$} & \multicolumn{2}{|c|}{ Non-visceral sites } & \multicolumn{2}{|c|}{ Visceral sites } & \multirow[b]{2}{*}{ Total } \\
\hline & & Men & Women & Men & Women & \\
\hline Sarcoma, NOS† & $8800 / 3$ & - & - & - & $2 \ddagger$ & 2 \\
\hline Spindle cell sarcoma & $8801 / 3$ & - & 1 & - & $1 \S$ & 2 \\
\hline Fibrosarcoma & $8810 / 3$ & 1 & - & - & - & 1 \\
\hline Fibromyxosarcoma & $8811 / 3$ & 1 & - & - & - & 1 \\
\hline Malignant fibrous histiocytoma & $8830 / 3$ & 1 & 3 & - & - & 4 \\
\hline Dermatofibrosarcoma protuberans & $8832 / 3$ & 3 & 3 & - & - & 6 \\
\hline Myxosarcoma & $8840 / 3$ & 1 & - & - & - & 1 \\
\hline Liposarcoma, NOS $†$ & $8850 / 3$ & 5 & - & - & - & 5 \\
\hline Liposarcoma, well differentiated & $8851 / 3$ & 2 & 1 & - & - & 3 \\
\hline Liposarcoma, myxoid & $8852 / 3$ & - & 2 & - & - & 2 \\
\hline Leiomyosarcoma, NOS $†$ & $8890 / 3$ & 1 & - & 2 व & 6 ** & 9 \\
\hline Angiosarcoma & $9120 / 3$ & - & - & - & $1 \dagger \dagger$ & 1 \\
\hline Subtotal & & 15 & 10 & 2 & 10 & \\
\hline Total & & 25 & & 12 & & 37 \\
\hline \multicolumn{7}{|c|}{$\begin{array}{l}\text { *ICD-O, International Classification of Diseases for Oncology. }{ }^{16} \\
\text { †NOS, no other specification. } \\
\text { fUterus. } \\
\text { §LLung. } \\
\text { \Stomach (1), thyroid (1). } \\
\text { **Uterus (3), stomach (1), ileum (2). } \\
\text { ††Breast. }\end{array}$} \\
\hline
\end{tabular}

According to a recent survey, ${ }^{13}$ emissions from the industrial area and urban pollution "stagnate" over the whole Mantua area for most of the year, especially during the cold season.

Although no data on TCDD levels in environmental or biological matrices are available, it is apparent that the incinerator was for many years a potential source of dioxin release into the environment.

In order to evaluate the association between residence in the neighbourhood of the incinerator and occurrence of STS, a case-control approach was adopted.

The survey was carried out for the period 1989-98, the most recent decade for which information on cases was available. Cases were adult subjects with histologically confirmed primary malignant STS originating in non-visceral and visceral locations, retrieved from the pathology archives and hospital admission/discharge forms recorded at the local health authority. Inclusion criteria were based on the histological categories of the Enzinger and Weiss soft tissue tumour classification, ${ }^{14}$ which is similar to the WHO classification, ${ }^{15}$ and the recommendations of the Association of Directors of Anatomic and Surgical Pathology.$^{16}$ Histological types were linked to the corresponding ICD-O/SNOMED morphological codes. ${ }^{17}{ }^{18}$ Mesothelioma (9050/3, 9051/3, 9052/3, 9053/2) and Kaposi's sarcoma (9140/3) were excluded.

A final listing of cases was obtained on further investigation of STS cases in Mantua residents diagnosed outside the Mantua province. The use of many sources (pathology files and admission/discharge records from all of Lombardy and pathology files from hospitals located in parts of Venetia and Emilia regions) rendered the survey exhaustive. For each subject the following information was collected: age, sex, year of diagnosis, site and histological type of the tumour, vital status, and date of death. The case ascertainment procedure did not include revision of the slides, but the actual pathology reports were scrutinised in detail.

Controls were randomly extracted from population registries, in order to reflect the proportion of the population resident in the different districts of Mantua and in the three neighbouring municipalities, with age and sex frequency matching.

Residential history since 1960 was reconstructed for all study subjects; "main residence" was defined as longest held address after removing the last 10 years before diagnosis (for cases) or before recruitment (for controls). This information was retrieved from existing sources; no interviews were performed. Main residence for all study subjects was geographically positioned according to GPS standards. Employment in the chemical plant was estimated for cases and controls by cross checking their names and demographic data against the database of a cohort study relative to the Mantua chemical plant, 1957-86. ${ }^{19}$ Data analysis, including logistic regression, was performed by means of STATA 1999 software and was based on main residence as defined above.

The analysis of STS risk and distance from the incinerator was performed using rings of $1 \mathrm{~km}$ radius; the first ring had a radius of $2 \mathrm{~km}$ because a large part of the area was inside the industrial area, and no one was obviously residing there.

The present study was triggered by a previous report of a cluster of STS cases around the Mantua industrial area. ${ }^{12}$ The time window of the two studies was different, and only one case met the admissibility criteria of both studies. Analysis was thus performed, both including and excluding that case.

\section{RESULTS}

The study includes 37 STS cases (17 men and 20 women), aged 26-85 years, and 171 controls ( 82 men and 89 women), aged 24-90 years. The mean age of cases (at diagnosis) and of controls (at recruitment) was, respectively, 60.9 (14.8) and 59.9 (15.7).

Sixty five per cent of the STS cases were non-visceral, with a predominance of male subjects, while among visceral cases the proportion of women was higher (table 1).

The annual incidence of soft tissue sarcomas in the area of study was estimated as 5.0 per 100000 in men and 5.1 per 100000 in women.

The association between occurrence of soft tissue sarcoma and distance of main residence from the incinerator was evaluated by logistic regression; the odds ratio associated with residence within $2 \mathrm{~km}$, standardised by age and sex, was 31.4 (95\% CI 5.6 to 176.1), based on five exposed cases (tables 2 and 3). At greater distances, risk rapidly decreased, showing a fluctuation around the null value of 1 . When the distance of the main residence from the incinerator was considered as a continuous variable, a non-significant decrease in risk with 
Table 2 STS risk and distance of main residence from incinerator

\begin{tabular}{lcccl}
\hline $\begin{array}{l}\text { Distance of the main residence } \\
\text { from the incinerator }(\mathrm{km})\end{array}$ & Cases $(\mathrm{n})$ & Controls $(\mathrm{n})$ & $\mathrm{OR}^{*}$ & $95 \% \mathrm{Cl} \dagger$ \\
\hline$\leqslant 2$ & 5 & 1 & 31.4 & 5.6 to 176.1 \\
$2-3$ & 3 & 26 & 0.7 & 0.2 to 3.1 \\
$3-4$ & 11 & 57 & 1.2 & 0.4 to 3.4 \\
$4-5$ & 11 & 43 & 1.6 & 0.6 to 4.5 \\
$>5$ & 7 & 44 & 1 & \\
\hline
\end{tabular}

*OR, odds ratio, adjusted by age and gender.

$\dagger \mathrm{Cl}$, confidence interval.

\begin{tabular}{|c|c|c|c|c|}
\hline Gender & $\begin{array}{l}\text { Distance from the } \\
\text { incinerator }(\mathrm{km})\end{array}$ & $\begin{array}{l}\text { Histology } \\
\text { Anatomical site }\end{array}$ & $\begin{array}{l}\text { Previous employment in } \\
\text { the Mantua chemical plant }\end{array}$ & $\begin{array}{l}\text { Year of } \\
\text { diagnosis }\end{array}$ \\
\hline Male & 1.35 & $\begin{array}{l}\text { Dermatofibrosarcoma protuberans } \\
\text { Thorax, skin }\end{array}$ & Yes & 1996 \\
\hline Female & 1.36 & $\begin{array}{l}\text { Liposarcoma myxoid } \\
\text { Stomach }\end{array}$ & No & 1993 \\
\hline Female & 1.78 & $\begin{array}{l}\text { Leiomyosarcoma, NOS* } \\
\text { Stomach }\end{array}$ & No & 1990 \\
\hline Female & 1.81 & $\begin{array}{l}\text { Liposarcoma myxoid } \\
\text { Thorax }\end{array}$ & No & 1996 \\
\hline Female & 1.97 & $\begin{array}{l}\text { Leiomyosarcoma, NOS } \\
\text { Uterus }\end{array}$ & No & 1993 \\
\hline
\end{tabular}

increasing distance was observed (OR 0.90; 95\% CI 0.73 to 1.1). Of the five cases who lived within $2 \mathrm{~km}$ from the incinerator, one male patient affected by dermatofibrosarcoma protuberans had previously been employed as a chemical worker in the Mantua plant, while four female patients (two cases of liposarcoma and two cases of leiomyosarcoma) had not been employed in the plant. Removing the chemical worker from the analysis caused a small decrease of the association which maintained statistical significance (OR 25.1; 95\% CI 4.2 to 150.8).

\section{DISCUSSION}

Before a critical evaluation of the study findings, some comments on validity issues are needed. The first question to be addressed is the case definition. The diagnosis of STS is quite complex because of the overlapping of some morphological aspects of these tumours with other neoplasms and because of their heterogeneity. ${ }^{14-17}$ No panel revision of the original specimen was feasible, but clinical records and pathological reports were thoroughly reviewed and checked. It is well known that the histological classification of STS includes hundreds of variants. The 37 cases of STS identified in Mantua during the study period belonged to 11 histological variants. Soft tissue sarcomas are a highly heterogeneous group of tumours and their exact pathogenesis is still unknown. ${ }^{14}$ The epidemiological association between STS and exposure to chlorophenols and phenoxyacids concerns the whole nosological entity, with no other histogenetic specification. ${ }^{1-7}$

The second aspect of the study design that needs to be discussed is the assessment of exposure. In the absence of an exposure categorisation based on environmental monitoring of dioxin, it seemed reasonable to use distance between residence and hypothesised source of emission as an indirect exposure estimate. This approach has mainly been used in small area studies of various chemical and physical environmental agents; it was recently applied to the association between STS and emissions of an incinerator in France. ${ }^{20}$

The main finding of the present paper is an increased occurrence of STS in the population living closest to the industrial incinerator. Emissions of a large industrial area like the one in Mantua include volatile organic compounds, heavy metals, polycyclic aromatic hydrocarbons, and chlorinated compounds such as PCDDs and PCDFs. Evidence of an association with STS is so far available for dioxins, but not for most of the other aforementioned compounds; since dioxins can be emitted from incinerators, it seemed reasonable to suspect a possible causal connection. As diet is the main route of exposure for dioxins, this hypothesis subsumes contamination of soil and food chain over the years and will have to be adequately tested.

With regard to possible confounding variables, they should both be associated with distance from the incinerator, and causally related to STS occurrence. ${ }^{21}$ Phenoxy herbicides do not meet this definition, since no major farming takes place in the neighbourhood of the industrial area of Mantua and no other hypothesised confounding variable seems to be supported by available evidence. The majority of cases in this study were resident in the town of Mantua (fig l) as could be predicted by population density. The hospital incinerator was suggested as possible source of TCDD emission in the central part of the town, but spatial analysis did not show any trend of risk with distance from the hospital.

A sharp drop off in the effect of distance from the incinerator was apparent in this study, although there was no continuous trend. This observation is consistent with a localised increase in exposure patterns, that did not extend to the urban setting (fig l). This hypothesis requires confirmation or refutation from environmental and biological monitoring.

The present study was initiated subsequent to the report of a possible cluster, in accordance with procedures currently recommended in guidelines from the USA ${ }^{22}$ and UK. ${ }^{23}$ Of the five cases of the original cluster, only one was included in the present study because of a different time window; if that case were removed, the odds ratio in the $2 \mathrm{~km}$ frame would decrease to 25.1 (95\% CI 4.2 to 150.8). The study was based on existing records and no subjects were interviewed, thus preventing the possibility of recall bias. Sample size was obviously limited, but the odds ratio was increased and the lower limit of its confidence interval exceeded unity.

Prior to this report, almost all epidemiological studies on soft tissue sarcomas investigated occupational exposure to dioxin contaminated agents. One study from Finland reported 
an increase in mortality from soft tissue sarcomas in the population living in a district where drinkable water contained $70-140 \mathrm{mg} / \mathrm{l}$ of chlorophenols due to leakages into the water from a wood industry. ${ }^{24}$ The aforementioned French study provided a standardised incidence ratio of 1.44 $(p=0.04)$ for residence around the incinerator of solid urban waste.

In the Seveso area, after accidental TCDD release in 1976, no death from STS was detected in the most severely affected A and $\mathrm{B}$ zone ( 0.8 expected), while four deaths occurred in the highly populated, less affected $\mathrm{R}$ zone (4.8 expected) from 1977 to $1996 .^{25}$

To our knowledge, this is the first reported case-control study showing an increased risk of soft tissue sarcoma in a population potentially exposed to dioxin because of residence in the neighbourhood of an industrial waste incinerator. A survey of dioxin concentrations in various matrices in the study areas is in progress.

\section{ACKNOWLEDGEMENTS}

The authors wish to thank Dr Fabrizio Oleari from the Ministry of Health for his support, Prof. Olav Axelson from the University of Linköping, Dr Franco Berrino from the National Cancer Institute in Milan, Prof. Cesare Cislaghi from the University of Milan, and Dr Marco Martuzzi from WHO for helpful suggestions and criticism.

\section{Authors' affiliations}

P Comba, S Belli, M Benedetti, National Institute of Health (ISS), Rome, Italy

V Ascoli, Department of Experimental Medicine and Pathology, "La Sapienza" University, Rome, Italy

L Gatti, P Ricci, Unit of Occupational Health, Local Health Authority, Mantua, Italy

A Tieghi, City of Mantua, Mantua, Italy

\section{REFERENCES}

1 Hardell L. Soft tissue sarcomas and exposure to phenoxy acids. A clinical observation. Lakartidningen 1977:74:2753-4.

2 Hardell L, Sandström A. Case-control study: soft tissue sarcomas and exposure to phenoxyacetic acids or chlorophenols. Br J Cancer 1979;39:711-17.

3 Eriksson $M$, Hardell L, Berg NO, et al. Soft tissue sarcomas and exposure to chemical substances: a case-referent study. $\mathrm{Br} J$ Ind Med $1981 ; 38: 27-33$

4 Kogevinas M, Kauppinen T, Winkelmann R, et al. Soft-tissue sarcoma and non-Hodgkin lymphoma in workers exposed to phenoxy-herbicides, chlorophenols and dioxins: two nested case-control studies. Epidemiology 1995;6:396-402.

5 Kogevinas $\mathbf{M}$, Becher $\mathrm{H}$, Benn $\mathrm{T}$, et al. Cancer mortality in workers exposed to phenoxy-herbicides, chlorophenols and dioxins. Am J Epidemiol 1997;145:1061-75.

6 International Agency for Research on Cancer (IARC).

Polychlorinated dibenzo-para-dioxins. In: IARC monographs on the evaluation of carcinogenic risk to humans. Polychlorinated dibenzo-para-dioxins and polychlorinated dibenzofurans. Lyon: IARC, 1997;69:33-343.

7 Axelson 0 . The epidemiologic evidence of health effects of tetrachlorodibenzodioxin (TCDD) in human beings. In: Ballarin-Denti $A$ Bertazzi PA, Facchetti S, et al, eds. The Seveso accident 20 years on. Elsevier Science Ltd, 1999:29-38.

8 Rappe C. Dietary exposure and human levels of PCDDs and PCDFs. Chemosphere 1992;25:231-4.

9 Bolm-Audorff U, Menzel HM, Murzen R, et al. Dioxin and furan occurrence due to employment in solid-waste incinerator. Verhandl Arbeitsmed 1994;34:105-8.

10 Päpke O, Ball M, Lis A, et al. Occupational exposure of chemical waste incinerators workers to PCDD/PCDF. Organohalogen Compounds 1994;21:105-10.

11 Menzel HM, Turcer E, Bienfait HG, et al. Exposure to PCDDs and PCDFs during welding, cutting and burning of metals. Organohalogen Compounds 1996;30:70-5

12 Costani G. Incidenza anomala di sarcomi dei tessuti molli a Mantova [Unusual incidence of soft tissue sarcomas in Mantua]. Epidemiol Prev 1998;22:1

13 Soggiu E, Marsili G, Sellitri C, et al. Studio del contributo industriale all'inquinamento atmosferico nel Comune di Mantova. In: Marsili G, ed. La valutazione del rischio d'area. Il caso dell'area industriale di Mantova. Milan: Franco Angeli, 2000:97-153.

14 Weiss SW, Goldblum JR. Enzinger and Weiss's soft tissue tumors, 4th edn. St Louis: Mosby, 2001:1-19.

15 Weiss SW, Sobin SH. Histological typing of soft tissue tumours, 2nd edn. WHO International Histological Classification of Tumours. Berlin: Springer Verlag, 1994.

16 Association of Directors of Anatomic and Surgical Pathology. Recommendations for the reporting of soft tissue sarcomas. Human Pathol 1999;30:3-7

17 Fritz A, Percy C, Jack A, et al. International classification of disease for oncology (ICD-O), 3rd edn. Geneva: WHO, 2000.

18 http://med.jhw.edu/pathology/iad/autocode.html; http:// www.cap.org/html/public/snomed-intf.html; http://www.snomed.com.

19 Merler E, Ricci P, Colin D, et al. Cancer mortality in a cohort of styrene production workers. 25th International Congress on Occupational Health, Stockholm, 15-20 September 1996. Book of abstracts, 1996:210.

20 Viel JF, Arveux P, Baverel J, et al. Soft tissue sarcoma and non-Hodgkin's lymphoma cluster around a municipal solid waste incinerator with high dioxin emission levels. Am J Epidemiol 2000;152:13-19.

21 Blair A, Stewart WF, Stewart PA, et al. A philosophy for dealing with hypothesized uncontrolled confounding in epidemiological investigations. Med Lav 1995;86:106-10.

22 Center for Disease Control (CDC). Public health service statement on management of occupational exposure to human immunodeficiency virus, including consideration regarding zidovudine postexposure use. Recommendations and reports. US Department of Health and Human Services Public Health Service. Morb Mortal Wkly Rep 1990;39:1-23.

23 University of Leeds. Handbook and guide to the investigation of clusters of diseases. Compiled at the Leukaemia Research Fund Centre for Clinical Epidemiology. University of Leeds, 1997

24 Lampi $\mathbf{P}$, Hakulien T, Loustarinen T, et al. Cancer incidence following chlorophenol exposure in a community in Southern Finland. Arch Environ Health 1992;47:167-75.

25 Bertazzi PA, Consonni D, Bachetti S, et al. Health effects of dioxin exposure: a 20-year mortality study. Am J Epidemiol 2001;153:103144 